\title{
EchoGéo
}

$53 \mid 2020$

Dénominations plurielles. Quand les noms de lieux se concurrencent

\section{Plural Toponyms: When Place Names Coexist} Introduction

Frédéric Giraut

(2) OpenEdition Journals

Electronic version

URL: https://journals.openedition.org/echogeo/20760

DOI: $10.4000 /$ echogeo.20760

ISSN: 1963-1197

Publisher

Pôle de recherche pour l'organisation et la diffusion de l'information géographique (CNRS UMR 8586)

\section{Electronic reference}

Frédéric Giraut, "Plural Toponyms: When Place Names Coexist ", EchoGéo [Online], 53 | 2020, Online since 25 October 2020, connection on 11 August 2021. URL: http://journals.openedition.org/echogeo/ 20760 ; DOI: https://doi.org/10.4000/echogeo.20760

This text was automatically generated on 11 August 2021.

EchoGéo est mis à disposition selon les termes de la licence Creative Commons Attribution - Pas d'Utilisation Commerciale - Pas de Modification 4.0 International (CC BY-NC-ND) 


\title{
Plural Toponyms: When Place Names Coexist
}

\author{
Introduction
}

Frédéric Giraut

1 A branch of onomastics (the study of proper names) in linguistics, toponymy studies the origins, meanings and alterations of place names. In addition, this field involves a considerable amount of inventory work and classification in diverse contexts and on diverse scales, ranging from rural micro-toponyms to macro-toponyms (e.g. the names of territories engaged in international relations). There are for example nomenclatures and scholarly dictionaries of cities, regions and states, and international experts who work on the standardization and transcription of official names. The output of toponymy is used in history and geography to reconstruct the archaeologies of peopling, landscape and the environment, using the valuable indicators provided by the heritage of place names. Finally, linguistics considers toponymy when working on linguistic landscapes. The question of naming, its motives, and the potential controversies it raises remain understudied and appear as a cross-disciplinary field. Naming places is indeed an essential human operation of territorialization, at the very core of political geography.

2 In recent years, an international current of political or critical toponymy has been considering the naming process to complement the study of names themselves. The focus is on the political, functional and identity-related implications of studies of place naming. Studies are thus dedicated to the production and evolutions of the toponomascape (or toponymical landscape), which forms part of the linguistic landscape at large. Whether official or unofficial, whether stemming from legal procedure or from practice, naming can be regarded as a social technology that assigns certain places and territories a function and a set of references, and contributes to establishing and/or revealing a social and political order.

3 In addition to the academic interest in toponymy as a means of reconstructing peopling and historical relations to the environment, scholars have investigated toponymy's geopolitical dimension on diverse scales (Azaryahu 1996; Monmonier 1996; Zelinski 
1997; Guillorel 1999; Kadmon 2000). However, in the 2000s and 2010s, analytical frameworks were established, identifying key areas with their respective hotspots (Alderman 2008; Giraut and Houssay-Holzschuch 2008a; Berg and Vuolteenaho 2009; Rose-Redwood et al. 2010; Bigon 2016; Puzey and Kostanski 2016). In addition, theoretical hypotheses were presented to interpret the motivations and practices of nomination, stemming from linguistics (Tent and Blair 2007) or political science, with approaches inspired by Foucault, Debord and Gramsci based on dispositifs, spectacularization and hegemony (Vuolteenaho and Kolamo 2012; Giraut and HoussayHolzschuch 2016). Major developments emerged in books, journal issues or synthetic studies on topics such as the remembrance value of street names (Bulot and Verschambre 2006; Rose-Redwood et al. 2018), place name commodification (Light and Young 2014; Medway and Warnaby 2014) or the naming of territorial rearrangements and "new regionalism (Giraut and Houssay-Holzschuch, 2008b).

4 This issue investigates the many and diverse toponymic situations where usages, cartography and nomenclatures reveal a multiplicity of sometimes conflicting denominations, that function according to different registers. These frequent and rich situations can be interpreted in light of political and cultural geography as indicators of a plurality of representations and practices, but also of historical relations to space and potential claims on these spaces. Such plural denominations have so far attracted the attention of researchers when they manifest competing territorial claims, and form part of geopolitical conflicts. For instance, some publications have studied the name of Macedonia, used in Greece and claimed for more than 20 years by the authorities of present-day Northern Macedonia (Tziampiris 2012; Mavromatidis 2010); or the name of the West Sea vs. the Sea of Japan (Short \& Dubots 2020); or that of the West Bank vs. Judea-Samaria (Cohen and Kliot 1992; Leuenberger and Schnell 2010). On the other hand, the multiple names of everyday places are largely ignored: streets, landmarks, crossroads, neighborhoods, towns or small regions.

5 And yet the plurality of names given to the same places in these situations and at these scales raises numerous, rich and original questions, as shown by the collection of articles gathered in this issue. In diverse contexts ranging from war zones to contemporary heritage, from large North American cities to large African cities, and from the French rural world to rural Nepal, contributions explore the modalities of the production and appropriation of multiple and potentially contradictory names, and the diverse claims associated with these names. What is generally at stake is the question of the endonym versus the exonym, or the vernacular versus the official. However, these binary oppositions are somewhat reductive, and can conceal more complex situations, often involving hybridizations.

6 The battlefields of the First World War provide a unique and paradigmatic situation illustrating the production of a new layer of place names endowed with a functional and symbolic value, in an already dense toponymic landscape. In just a few months and for several years, a "war city" was built on rural land, hosting millions of people in very dense temporary facilities. The setting up of this international city gave rise to an unprecedented process of temporary but very real naming, which shaped the soldiers' daily environment. This wartime toponymy was superimposed on the rural microtoponymy, which it partially recycled. At the end of the conflict, far from disappearing completely with the dismantling of military settlements, the wartime toponymy was perpetuated through the landscape of commemoration, which in some cases remained 
the only occupation of this space; more often than not, a selective toponymic remembrance was maintained in conjunction with the rural landscape that partially regained its rights. Alain Devos, Pierre Taborelli and Robin Perarnau's article studies the names of trenches and tunnels in Champagne as registered by military maps ("Canevas de Tirs") in 1918. The inventory and typology conducted by the authors capture the conditions of production of these names by the military authorities via the regiments and companies, guided by practical and functional military principles. The place names thus produced were heterogeneous but responded to a combination of logics. From a practical perspective, the reuse of some elements drawn from the toponymic heritage re-organized original micro-toponymy to produce new names that took on a strategic military value. In addition, the nomenclature of new names also responded to practical classification needs (one given theme and first letter for each sector), but also to the troop's need for appropriation, using references to heritage, history and to the regiment or company's place of origin, and celebrating their exploits and martyrs. Finally, another marginal but significant logic was that of sarcastic or ironic vernacular denominations, referring to the enemy, living conditions and casualties.

7 Clément Millon's article also investigates the toponymy of World War One, but this time through the commemorative odonymy developed in later years, as recorded by the nomenclature of streets and squares in French towns and cities. This can be regarded as a case of plural denomination, as it created a distinct memorial category that was reproduced in the odonymic landscape alongside other categories. For example, the French odonymy associated with the Great War highlights one particular date - November $11^{\text {th }}, 1918$, which is the date of the Armistice that marked the end of the conflict - as well as one particular value: Peace (as shown by street names like "Rue de la Paix") although this term is not explicitly associated with a specific period. Personalities are also commemorated, in particular Foch and Clémenceau who embody two aspects of the Nation that came together to defend it. The specificity of these commemorations, their geography and long-term aspects, is examined in comparison with those of other major conflicts including World War Two. From this point of view, the meaning of World War One toponyms appears to be partially fading and to focus less on human involvement. In contrast, World War Two is commemorated through a few major figures (Général De Gaulle, Maréchal Leclerc, Jean Moulin), but also through the memory of the liberation, resistance and martyrdom. World War One also enjoys a very concrete and visible presence in the French landscape through war memorials. This war is also very present in the odonymy through the evocation of battles, but these occurrences are more difficult to identify as the signifiers are place names that do not only refer to a battle. This case illustrates various aspects of toponymic plurality, but in this case it is applied to multiple references to one same place.

Ghousmane Mohamed presents an overview of the Saharan Tuareg onomastic, with a focus on the current space of Niger. This exploration of the linguistic and semantic roots of Tuareg toponymy emphasizes this society's mobility. The naming techniques integrate places both into a mobile yet coherent socio-spatial system, and in an environment that is reinterpreted according to its uses and to circulation. This toponymy is thus transposable (further studies on Tuareg toponymic projection in cities would be welcome), and forms a non-exclusive heritage marker of Saharan spaces. 
Christophe Gauchon's article also touches on heritagization, but this time on a global scale, by considering the naming of sites on the UNESCO World Heritage List. This article documents the very diverse compositions and references types that are coined as a token of these sites' universal value - which is a condition of their inscription on the List, and incidentally of their touristic value (Neotoponymy, 2019). The names inscribed on the List reveal the political issues at stake on multiple scales in contemporary heritage. The author delivers an inventory of names and analyses their motivations, showing among other things a trend towards the restoration of indigenous toponyms to replace exonyms inherited from the colonial period. This process is often motivated by the postcolonial search for historical authenticity regarding the cultural and natural heritage, but it can also serve nationalist purposes for example when the Nepalese name of the "Roof of the World" is promoted by preference over the name of its English "discoverer" of course, but also over its older Tibetan name. In the case of Catalonia, the promotion of regional references can also hint at a certain nationalism, which is even more obvious when a reference to the name of the state is added; similarly, in Switzerland, mentions of the national state are used, at the risk of tautology, to overcome divisions into cantons.

Darshan Karki and Miriam Wenner study the use of ethnonyms as toponyms to refer to the territories of the Nepalese Lowlands, analyzing the political and identity dimensions of neotoponymy. The authors show how the elite's territorial and toponymic claims are associated with their sense of belonging to a group that cuts across language, religion and caste, which comes in conflict with nationalist rhetoric. While these toponymic claims stem from an essentialist approach - which also has strategic aspects (Giraut, 2017) -, they come up against the exclusionary dimension of ethnonymic denominations.

11 In contrast with the naming of contemporary administrative territories, the toponymy conveyed by tales and legends - in other words, oral tradition - can in certain contexts prove more powerful in promoting or preserving the vernacular toponymy and imagination. This is what Jean-Baptiste Bing shows, based on the examples of hyperurban and hyper-rural tales and legends from respectively Paris and the Morvan region, that manifest different political, or rather infra-political, uses of oral tradition. These narratives reveal and invoke a toponymy that promotes alternative uses of places in reaction to a contested project (planting conifers) or development (burying a river).

12 The subversive power of vernacular toponymy appears even more clearly in the naming of neighborhoods and landmarks in informal African cities. Working from the example of Yaoundé, Gaston Ndock Ndock shows the polyphony that arises in spontaneously urbanized districts, when standardization operations go along with attempts to impose official place names while vernacular names still remain in use. For example, a road crossing humorously named "I wasted my life" after which the entire neighborhood was named, resists its new name of "Nelson Mandela". This official commemoration, imposed by the public authorities, would not only associate the great man with a place whose key characteristic is its bad reputation; but above all, it would silence the challenge to the authorities expressed by this ironic name, which both asserts and laments the area's marginal condition.

13 In the secondary city of Bindura, Zimbabwe, Dorcas Zuvalinyenga highlights the diversity of place names in simultaneous use. The various corpuses all have their own 
particularities. While the official layer inherited from the colonial period mostly refers to exonyms - or more precisely, to external references -, the official postcolonial layer is linked to the regime, its history, ideology and stated achievements. However, all these official corpuses share the same gender bias, which excludes the feminine. In contrast, the vernacular corpuses that result from spontaneous naming practices express, sometimes ironically, the concerns of marginalized groups, including young people, vulnerably housed people or speakers of minority languages.

, three different names illustrate the tension between competing registers for the naming of the city's "open drug use scene" - in other words, an urban area where the sale and consumption of drugs is practiced and where drug users are supported through the provision of substitutes. At the intersection of several neighborhoods marked by their contrasting social dynamics, the different names in use for this sector either stigmatize, enhance or hide the "open scene" that characterizes it. This original case study by Elsa Vivant illustrates the role of vernacular toponymic creativity, in a context that is not one of spontaneous urbanization, but of a tension between urban social problems and gentrification.

15 Finally, Fabio Armand and Jean-Pierre Gerfaud address the question of tautology in toponymy, which has already been discussed. They consider the case of toponyms made up of two elements drawn from two different languages, but that have the same conceptual meaning. In this case, toponymic plurality is evident in compound names. Examining the conditions of linguistic production of these names, the authors show that they appear in circumstances where a change occurred in the area's peopling and in the status of languages: the old name is retained but becomes "demotivated" (i.e. it only refers to the place but no longer to the generic concept that described it) (Kristol, 2002), and is then supplemented by a reference to the same concept in the nominators' language. The tautological neo-toponym thus associates a demotivated endonym in the former vernacular with a neonym of the same meaning in the vehicular language. For example, the name of the Col de la Forclaz in Haute-Savoie (the same toponym can be found nearby but on the other side of the border, in the Swiss canton of Valais) associates the name "col" (mountain pass) in French (the national vehicular language) with that of Forclaz, whose ending is specific to the Franco-Provencal Alpine dialect, and which originally means fork in Latin, indicating the idea of a crossroads in a mountain pass. This toponymic tautology goes beyond the opposition of vernacular versus official or generic language: it manifests a hybrid linguistic landscape that testifies to the contact and encounter of languages, populations and political and cultural traditions.

One of the most obvious lessons from this set of studies and analyses is the richness and political power of vernacular language when it competes with official language, in contexts as diverse as cities in the South or in the North, or heritage sites of different scales. Theoretically speaking, situations of toponymic plurality raise questions as to the binary opposition between exonym/endonym, by highlighting the relational and sometimes relative dimension of these two registers (Woodman, 2012). Finally, methodologically speaking, the identification of these numerous situations opens the way for a study of their cartographic expression in a context where cartographic media is proliferating on the geoweb (Noucher, 2020). Indeed, the end of the public monopoly on geographic information - or cartographic sovereignty - opens the way for the 
promotion of potentially competing toponymic corpuses (whether private, vernacular or official) in signage and in various online or embedded media.

\section{BIBLIOGRAPHY}

Alderman D., 2008. Place, naming, and the interpretation of cultural landscapes. In Graham B. and Howard P. (ed.), The Ashgate research companion to heritage and identity. Aldershot, Ashgate Press, p. 195-213.

Azaryahu M., 1996. The power of commemorative street names. Environment \& Planning D: Society \& Space [En ligne], vol. 14, n 3, p. 311-330. DOI: https://doi.org/10.1068/d140311

Berg L. D., Vuolteenaho J. (ed), 2009. Critical Toponymies: The Contested Politics of Place Naming. Aldershot, Ashgate Press.

Bigon L. (ed.), 2016. Place Names in Africa. Colonial Urban Legacies, Entangled Histories. Cham, Springer.

Bulot T., Veschambre V. (ed.), 2006. Mots, traces et marques. Dimensions spatiales et linguistiques de la mémoire urbaine. Paris, L'Harmattan.

Cenoz J., Gorter D., 2006. Linguistic landscape and minority languages. International Journal of Multilingualism, vol. 3, $\mathrm{n}^{\circ}$ 1, p. 67-80.

Cohen, S. B., Kliot N., 1992. Place-Names in Israel's Ideological Struggle over the Administered Territories. Annals of the Association of American Geographers, vol. 82, n 4, p. 653-680.

Giraut F., Houssay-Holzschuch M., 2008a. Au nom des territoires! Enjeux géographiques de la toponymie. L'Espace géographique, vol. 37, n², p. 97-105.

Giraut F., Houssay-Holzschuch M., 2008b. Néotoponymie : formes et enjeux de la dénomination des territoires émergents. L'Espace politique, $\mathrm{n}^{\circ}$ 2, p. 5-12.

Giraut F., Houssay-Holzschuch M., 2016. Place Naming as Dispositif: Toward a Theoretical Framework. Geopolitics [En ligne], vol. 21, n 1, p. 1-21. DOI: https://doi.org/ 10.1080/14650045.2015.1134493

Giraut F., 2017. Frontières communautaires, ethno-régionalismes et apartheids. In Staszak J.-F. (ed.), Frontières en tous genres. Rennes, PUR, p. 81-102.

Guillorel H., 1999. Toponymie et politique. In Akin S. (ed.), Noms et re-noms : la dénomination des personnes, des populations, des langues et des territoires. Rouen, PUR-CNRS, p. 61-91.

Guillorel H. (ed.), 2008. Toponymie et politique : les marqueurs linguistiques du territoire. Bruxelles, Bruylant.

Kadmon N., 2000. Toponymy: the lore, laws, and language of geographical names. Vantage Press.

Kristol A. M., 2002. Motivation et remotivation des noms de lieux : réflexions sur la nature linguistique du nom propre. Rives nord-méditerranéennes, $\mathrm{n}^{\circ}$ 11, p. 105-120.

Leuenberger, C., Schnell I., 2010. The politics of maps: Constructing national territories in Israel. Social Studies of Science, vol. 40, $\mathrm{n}^{\circ}$ 6, p. 803-842. 
Light D., Young C., 2014. Toponymy as Commodity: Exploring the Economic Dimensions of Urban Place Names. International Journal of Urban and Regional Research [En ligne], vol. 39, n 3, p. 435-450. DOI: https://doi.org/10.1111/1468-2427.12153

Mavromatidis F., 2010. The Role of the European Union in the Name Dispute between Greece and FYR Macedonia. Journal of Contemporary European Studies, vol. 18, n 1, p. 47-62.

Medway D., Warnaby G., 2014. What's in a name? Place branding and toponymic commodification. Environment and Planning A [En ligne], vol. 46, n 1, p. 153-167. DOI: https:// doi.org/10.1068/a45571

Monmonier M., 1996. How to lie with maps. University of Chicago Press.

Noucher M., 2020. The Place Names of French Guiana in the Face of the Geoweb: Between Data Sovereignty, Indigenous Knowledge, and Cartographic Deregulation. Cartographica: The International Journal for Geographic Information and Geovisualization, vol. 55, n 1, p. 15-28.

Neotoponymy, 2019. Lascaux : du Lieu-dit à la marque globale. Note de recherche Blog scientifique Néotoponymie. URL : https://neotopo.hypotheses.org/2385

Puzey G., Kostanski L. (ed.), 2016. Names and Naming: People, Places, Perceptions and Power. Bristol, Multilingual Matters.

Rose-Redwood R. et al., 2010. Geographies of toponymic inscription: new directions in critical place-name studies. Progress in Human Geography [En ligne], vol. 34, n 4, p. 453-470. DOI: https://doi.org/10.1177/0309132509351042

Rose-Redwood R. et al. (ed.), 2018. The Political Life of Urban Streetscapes. London, Routledge. Short J. R., Dubots L., 2020. Contesting Place Names: The East Sea/Sea of Japan naming issue. Geographical Review [En ligne]. DOI: https://doi.org/10.1080/00167428.2020.1827936

Tent J., Blair D., 2009. Motivation for Naming: A Toponymic Typology. Technical Papers. A. N. P. Survey. Sydney, Linguistics Department.

Tziampiris A., 2012. The Macedonian name dispute and European Union accession. Southeast European and Black Sea Studies, vol. 12, $\mathrm{n}^{\circ}$ 1, p. 153-171.

Vuolteenaho J., Kolamo S., 2012. Textually Produced Landscape Spectacles? A Debordian Reading of Finnish Namescapes and English Soccerscapes. COLLeGIUM: Studies across Disciplines in the Humanities and Social Sciences, vol. 13, p. 132-158.

Woodman P. (ed.), 2012. The Great Toponymic Divide. Reflections on the definition and usage of endonyms and exonyms. Warszawa, Head Office of Geodesy and Cartography.

Zelinsky W., 1997. Along the Frontiers of Name Geography. The Professional Geographer [En ligne], vol. 49, n 4, p. 465-466. DOI: https://doi.org/10.1111/0033-0124.00092

\section{INDEX}

Subjects: Sur le Champ - Sur le Terrain 


\section{AUTHOR}

\section{FRÉDÉRIC GIRAUT}

Frédéric Giraut, frederic.giraut@unige.ch, is a Professor at Geneva University. He edits the blog https://neotopo.hypotheses.org/. His publications include:

- Giraut F., Houssay-Holzschulch M., 2017. Au-delà du toponyme, la dimension politique de la territorialisation par la nomination. In Pasquali S., Gonzalez J. (ed.), Au delà du toponyme.

Approches interdisciplinaires de la territorialité. Egypte et Méditerranée anciennes. Montpellier, ENiM. - Giraut F., Houssay-Holzschuch M., 2016. Place Naming as Dispositif: Toward a Theoretical Framework. Geopolitics, vol. 21, n 1, p. 1-21. DOI: https://doi.org/10.1080/14650045.2015.1134493 - Giraut F., 2017. Frontières communautaires, ethno-régionalismes et apartheids. In Staszak J.-F. (ed.), Frontières en tous genres. Rennes, Presses Universitaires de Rennes, p. 81-102. 